\section{Educational Topics and Events}

BirminghaM.-Colonel H. F. Humphreys has been appointed to the recently created chair of dental surgery. He was formerly lecturer in dental anatomy and curator of the Odontological Museum in the University.

CAmbridge.-The following committee has been appointed to advise the Council of the Senate in their choice of a Jacksonian professor of natural philosophy :- the Vice-Chancellor, W. Spens, Prof. Lennard-Jones, H. Thirkill, Prof. G. I. Taylor, Sir Frank Smith, Lord Rutherford, Sir William Pope and Lord Rayleigh.

The following resignations or retirements are announced :-J. T. Saunders, lecturer in zoology; A. A. Miles, demonstrator in pathology ; Dr. A. E. Barclay, lecturer in medical radiology and electrology; T. G. Room, lecturer in mathematics; Dr. J. Chadwick, lecturer in physics ; Dr. N. Feather, demonstrator in physics; H. N. Green, demonstrator in pathology; R. H. D. Mayall, lecturer in mathematics; Dr. G. F.C. Searle, lecturer and demonstrator in physics; Dr. S.M. Manton, demonstrator in comparative anatomy ; E. H. B. Boulton, lecturer in forestry.

R. Passmore has been elected Gwynaeth Pretty student, and Dr. M. E. Adair, of Girton College, John Lucas Walker student.

The John Wimbolt Prize has been awarded to E. D. Ward, of Gonville and Caius College, for a dissertation on "The Thermal Properties of Metals and their Engineering Significance".

At St. John's College, J. S. Marshall, Queen's University, Ontario, has been elected to an exhibition for physics, and G. H. Twigg, University of St. Andrews, to one for chemistry.

At Emmanuel College, the external studentship has been awarded to J. C. Bower (University of Melbourne), for physics.

AN account of the development of the Department of Industrial Administration in the College of Technology, Manchester, by Dr. K. G. Fenelon, has been reprinted from the "Year Book" of the Manchester College of Technology Old Students Association. The Department was founded in 1918 through the co-operation with the governing body of the College of eleven firms each of whorn contributed an annual sum of $£ 100$, and was developed with the special object of providing facilities for training in the broad underlying principles of management and administration. For the first few years, the Department's activities under the direction of Dr. Stanley Kent were largely devoted to research, but Mr. Dempster Smith who succeeded him as director in 1921 proceeded to develop the teaching side. Evening courses were then established, including those on administration for engineers and administration for chemists, and a full-time two-year day course in industrial administration was introduced, which in 1.926 was recognised for the associateship of the College. In 1926 a University post-graduate course in industrial administration was commenced, the first course of its type to be provided in Great Britain, and in the same year the Department was taken over entirely by the College, the original guarantors, with certain changes, continuing to act as an Advisory Committee, Dr. James A. Bowie succeeded Mr.
Dempster Smith as director in 1926 and was followed in turn by Dr. K. G. Fenelon in 1931. Research at present in progress includes scientific management in textile mills, budgetary control, works organisation with special reference to engineering industries and administration and organisation of transport enterprises. Experiments have been made with the 'case method' of instruction, and the full-time courses include weekly study visits to factories, offices and business enterprises.

Schools of the largest size are to be found, as is well known, in American cities. A recent monograph on the elimination of very small schools (Bull. No. 3, 1934, of the Office of Education) reveals the surprising facts that in the United States more than 7,000 State schools have not more than five pupils each and 1,000 have only one or two. Moreover, in some States the number of such very small schools tends to increase with the substitution of larger farms for smaller and rural depopulation. At a time when school costs are bearing heavily on reduced revenues, the expensiveness of maintaining these diminutive units is directing attention to various schemes for eliminating them. Consolidation into larger units of the ordinary type is among many communities impracticable because transportation facilities cannot be provided. Considerable interest has in recent years been aroused by the use of postal tuition for secondary education, and the question has now been raised whether such correspondence lessons might not with advantage replace many of the excessively small and costly rural schools. Australian and Canadian public school administrators are well satisfied with the results of primary education by correspondence under schemes which have been in operation for some fifteen years in Australia and British Columbia and seven years in Alberta, Sas. katchewan and Manitoba. A comprehensive account of the Australian schemes was published in 1931 by Melbourne University Press in association with Messrs. Macmillan and Co., Ltd. The author, Dr. K. S. Cunningham, while admitting that children so taught miss some valuable social experiences, was impressed by the compensating advantages accruing from the intellectual independence fostered in them through having to tackle their work without the present aid of a teacher.

\section{Science News a Century Ago}

\section{The Association of German Naturalists}

Writing from Bonn on September 28, 1835, to the Athenceum about the German Society "Der Naturforscher und Aerzte" which had just finished its meeting, a correspondent said : "The proceedings of this body must necessarily excite an increasing interest, when its offspring, the British Association, has been growing to its present colossal dimensions, although the subjects and discussions at these Meetings are less comprehensive than at the Association, being confined to Natural History in its widest extent, Anatomy and Chemistry. The results of both have been crowned with a success little expected by those who projected them". Among the most distinguished men of science at Bonn were Von Buch, Elie de Beaumont, Constant Prevost, Alexandre and Adolphe Brongniart, Littrow, Audouin, Ritter, Jussieu, Ampère and Weber, the British men of science including Buckland, Lyell, Horner, Greenough, Gregory and Turner. The first 